\title{
School Counselor and Non-Governmental Organization Collaboration for Disaster Preparedness in School
}

\author{
Dila Rahmawati* \\ Guidance and Counseling Department of Graduate School \\ Program \\ Universitas Negeri Yogyakarta \\ Yogyakarta, Indonesia \\ dilarahma1@gmail.com* \\ Saryono \\ Physical Education, Health, and Recreation Department, \\ Faculty of Sport Sciences \\ Universitas Negeri Yogyakarta \\ Yogyakarta, Indonesia \\ saryono@uny.ac.id
}

\author{
Diana Septi Purnama \\ Guidance and Counseling Department of Graduate School \\ Program \\ Universitas Negeri Yogyakarta \\ Yogyakarta, Indonesia \\ dianaseptipurnama@uny.ac.id \\ Soni Nopembri \\ Physical Education, Health, and Recreation Department, \\ Faculty of Sport Sciences \\ Universitas Negeri Yogyakarta \\ Yogyakarta, Indonesia \\ soni_nopembri@uny.ac.id
}

\begin{abstract}
Education for disaster preparedness is an important effort that needs to be mainstreamed in order to increase students' preparedness in the event of disaster. As school counselors and non-governmental organizations (NGOs) are among many parties responsible for conducting disaster preparedness education in school, possibilities for both parties to collaborate are wide-open. This study aims to identify types of collaboration between school counselors and nongovernmental organizations in conducting disaster preparedness education in school. This study was carried out using a qualitative descriptive method and involved four nongovernmental organizations as its subject selected using a purposive sampling method. The four subjects of the study included Hope Worldwide Indonesia, Plan Indonesia, Aksi Cepat Tanggap (ACT) and Indonesian Society for Disaster Management (MPBI). To collect data, researcher conducted interviews in focus group discussions (FGD), followed by analysis using a triangulation technique. Results indicated possibilities for school counselors and non-governmental organizations to collaborate in conducting education for disaster preparedness in school through the following actions: 1) participating in disaster preparedness training; 2) providing assistance in organization-school principal coordination in conducting disaster preparedness education in school; 3) conducting disaster simulation drills to prepare students mentally and change their behavior in the event of disaster; 4) spiritual mitigation through lectures or movies; 5) designing simple games on the theme of disaster preparedness; 6) designing child-friendly areas to protect children's psychosocial aspect; and 7) creating instrument to assess individual responses while panicking.
\end{abstract}

Keywords - collaboration, disaster preparedness, school counselor

\section{INTRODUCTION}

Indonesia is a country with high risks of disaster including earthquakes, volcanic eruptions, tsunamis, and monsoon storms. This is because Indonesia sits between the world's most active seismic area, notoriously known as "Ring of Fire", with 130 active volcanoes [1] and a complex puzzle of tectonic plates across islands [2]. The aforementioned factors have put the country at constant risk of disasters every year. Each year, the occurrences of natural disaster in Indonesia varied in number. The National Disaster Management Agency (BNPB) in its official websites released the latest information pertaining occurrences of natural disaster in Indonesia between 2018 and 2019 and declared 3,999 events within the period. Indonesia recorded a total of 1,064 floods, 829 landslides, 5 floods and landslides, 42 coastal abrasion, 1,372 whirlwind, 162 droughts, 425 forest and land fires, 40 earthquakes, 2 tsunamis, 2 earthquakes and tsunamis, and 56 volcanic eruption [3]

However, despite being prone to disaster, people in the country have not been prepared for catastrophes. BNPB research indicated that disaster preparedness level of Indonesian populations in 33 regions was lower than that of other countries. The lack of disaster preparedness has contributed to higher risks of disaster in Indonesia [4]. With almost 250 million populations, knowledge pertaining disaster preparedness has become a crucial aspect in reducing death risks caused by disaster [5]. Knowledge is the primary aspect to disaster preparedness as it influences individual behavior and care to stay alert and keep anticipating disasters in the surrounding [4]. Knowledge of disaster preparedness should be spread to all layers in the society particularly children, considering their vulnerability 
and need for special support in the event of catastrophes [6]. Nevertheless, children's strong potential to raise awareness of disaster risk education and increase knowledge that can significantly contribute to people's resilience in the long term should never be underestimated [7].

Knowledge of disaster preparedness can be spread in some ways, including education. Several researches argued that integrating education for disaster preparedness into school curriculum was the best approach to transfer knowledge of disaster risk reduction [8]. Education plays role in building resilience and efforts to mitigate disaster in the long term [9]. In order to create positive impacts on either knowledge or individual behavior to reduce the risks of disaster, education should be integrated into management and practice levels [8]. In line with the viewpoint, in 2018, the Ministry of Education and Culture of Republic of Indonesia collaborated with BNPB to create Education for Prevention and Reduction of Disaster Risks module available on website and accessible to anyone. Nonetheless, the spread of well design teaching materials is never a comprehensive solution to integrate disaster education in school [10] aiming at providing individuals and groups with knowledge of how to act to reduce vulnerability to disaster [11].

Disaster knowledge is a crucial basic to prepare students for disasters and therefore needs to be transferred as early as possible [12]. One of experts, Notoatmojo, argued that increased individual knowledge correlates with increased individual behavior [13]. Therefore, it can be inferred that the higher the knowledge of a student about a disaster, the higher his preparedness for the disaster. Improvement of disaster knowledge through education for disaster preparedness is required due to the fact that students are social power who are able to either present or reduce the risks of disaster [14] and that schools are responsible not only for teaching them knowledge about disaster preparedness but also as evacuation centers disaster-stricken residents [15]. On the other hand, schools are perceived as formal education institutions with capabilities of changing mindset and behavior of people effectively [16]. Consequently, school is one of targeted places that provides students with education for disaster preparedness due to its ability to neutralize future disasters or minimize impacts through improvement of disaster preparedness [17].

The providence of disaster preparedness education will certainly require all school personnel, including teachers, to cooperate. Teachers are involved because of the trust they earn from the students and their important roles in making students feel safe [18]. Not only subject teachers, school counselors also play important roles in assuring the success of disaster preparedness education. School counselors can take part by providing services to prevent and overcome psychosocial problems pertaining disaster preparedness in school. Prevention is based on the preventive function in guidance and counseling service applied in pre-disaster stage to minimize the impact of major disasters [19]. The process of providing services for prevention that refers to disaster preparedness education can be done through, for example, collaboration with experts in disaster preparedness such as non-governmental organizations (NGOs). Professional nongovernmental organizations in disaster preparedness are the drivers in advocacy program, which also provide facilities during the providence of disaster education [20]
However, in spite of NGOs' initiatives to create programs to drive disaster preparedness activities, challenges in the implementation of the program in school remain. They include: 1) difficulties in obtaining permits from related institutions, 2) the absence of long-term continuation efforts of the trainings that have been done together with the teachers, 3) failure to match teachers who participated in trainings to criteria set by the organizations, 4) assumption that there have been parties other than schools responsible for providing disaster preparedness education, 5) the long process of recovery disaster survivors should undergo, 6) the absence of disaster preparedness concept in the bureaucracy, 7) the lack of teachers' awareness and interest in implementing results of trainings conducted by the organizations, 8) inability of some teachers to transfer messages and materials delivered by the organizations to the students, 9) limited technological devices needed to play disaster preparedness games online, 10) unwillingness of individuals with no disaster experience to participate in disaster preparedness program, 11) the absence of instruments to assess individual responses under panic or unconsciousness, 12) the need for more fun ways to build discipline and positive response to face disaster among students, 13) the lack of supports from teachers and school principals despite importance of disaster preparedness education to change students behavior and prepare them mentally for disaster, 14) the need for child friendly spaces to maintain children's psychosocial conditions, and 15) the lack of spiritual mitigation [21].

Looking over the above challenges closely, some of them are parts of the jobs and authorities of school counselors in either preventing or overcoming. Hence, it is obvious that school counselors need to establish collaboration with NGOs in providing disaster preparedness education in order to contribute to establishment of physical and psychological preparedness. Through this study, researcher aims to identify types of collaboration between school counselors and nongovernmental organizations in conducting disaster preparedness education in school.

\section{METHODS}

\section{Research Design}

This study adopted a phenomenology qualitative approach. Phenomenological study aims at discovering facts of a social phenomenon. Phenomenology also attempts to understand individual behavior from the perspective of the participants [22].

\section{Subject}

Subjects of the study were selected using a purposive sampling method which was based on specific considerations/criteria. All non-governmental organizations involved in this study were selected based on a specific criterion: their focus on disaster mitigation and preparedness program. Referring to this criterion, researcher selected four national scale non-governmental organizations headquartered in Jakarta to take part in this study. The four non-governmental organizations included Hope Worldwide Indonesia, Aksi Cepat Tanggap (ACT), Indonesian Society for Disaster Management (MPBI), and Plan International Indonesia. 


\section{Instrument}

Data were collected throught semi-structured interviews aimed to identify various aspects in-depth, including how participants interpreted a situation or phenomenon that could not be found during observation [23]. Prior to the interview, researcher constructed an interview guideline based on the study focus to direct the researcher into asking relevant questions and digging in-depth information from the participants. Semi-structured interviews were conducted to gain information pertaining types of collaboration between school counselors and non-governmental organizations in conducting disaster preparedness education in school.

\section{Data Analysis Technique}

After being collected, data were then analyzed pursuant to Miles and Huberman theory and underwent three different stages, including: 1) data reduction, which included sorting and summarizing important and relevant data for the study; 2) data display, which involved presenting narrative data generated from data reduction stage in several categories or matrices; and 3) drawing conclusion or verification by finding the meaning of goods, patterns, explanations, recording regularity, configuration, cause-effect flows, or proposition [24].

\section{RESULT AND DISCUSSION}

\section{Result}

Results of the interviews suggested three types of collaboration between school counselors and NGOs in disaster preparedness education, including: preparation for providing disaster preparedness education, intervention in disaster preparedness, and products/innovations that can be developed. The three findings will be elaborated as follows.

1. Preparation for providence of disaster preparedness education

To prepare for disaster preparedness education in school, schools can send their counselors to disaster preparedness trainings. School counselors are required to participate actively in disaster preparedness regular meetings conducted by the organizations and to transfer the knowledge they obtain to other teachers in school. This finding is supported by a statement of the subject saying "It usually ended with schools saying thank you for the trainings without any further actions" [21]. "NGOs have set criteria and requested teachers based on the criteria (physical education or guidance and counseling teachers/school counselors) to participate in the training to avoid disturbing teaching and learning process in schools. It is expected that these teachers can do more than just copying what they get from the NGOs, but transferring what they obtain to others including subject teachers or class teachers." [21]. Besides involvement in trainings, school counselors can assist NGOs in coordinating with school principals in conducting disaster preparedness education as well as provide understanding that responsibilities for the program lie at the feet of all parties. Subject of the study supported by saying "Schools need to inform two different government agencies as it is difficult for NGOs to take part in the bureaucracy. This far, school efforts usually stop at expressing gratitude" [21]. "They still do not participate despite being invited over and over again. They assume that disaster preparedness education has been taken care by other parties. Advocacy provided by the organizations also seemed fruitless" [21].

\section{Types of intervention provided in disaster preparedness}

Interventions for students can include disaster simulations and mitigation in spiritual aspect. Disaster simulations are conducted based on potential types of disaster in the area where schools are. Simulations aim to change students' behavior and train them mentally to make sure they are ready when disaster strikes. Meanwhile, mitigation in spiritual aspect can be done by adopting either lecturing method or technology to play movies. Mitigation services aim at increasing students' awareness that human destructive behavior such as sinful acts, littering, and bribing people to fire the forests are linked to God's wrath. Some of the statements declared by subjects of the study to support this include: "Simulations are needed and should be adjusted to the types of disaster in the area" [21]. "Preparedness is about mental preparation. It is how people respond best to disaster and not panicking. It can be preventive through drills to see how they should respond when disaster strikes. If children are prepared, their conscious state of mind will respond to disruption according to what they learn in the simulations" [21]. "Mitigation in spiritual aspect is needed. Children should know that human deeds and God's wrath are linked. Sinful acts, littering, and bribing people to fire the forest are all bad deeds. Children should know that" [21].

\section{Products/innovations to be developed}

Together, school counselors and NGOs collaborate to design various simple games adopting disaster preparedness theme. The games are used for both preventive and curative purposes and designed for non-electronic media use. In addition to games, child friendly spaces should also be designed to maintain children's psychosocial conditions. Another product that needs to be developed is instrument for assessing individual responses to panic situation or even unconsciousness. This instrument is important to find out spontaneous responses of individuals in the event of disaster. Creation of this instrument is crucial due to absence of instrument to assess panic level of individuals in disaster. Subject argued that "I agree with the creation of game-based disaster preparedness activities as they bring joy to students and eliminate impression of coercion in their implementation" [21]. "No Internet is needed in the games as not all regions in Indonesia have access to electricity and Internet" [21]. "Children need to have child friendly spaces to maintain their psychosocial conditions" [21]. "This far, there have been no instruments that precisely assess the actual responses of individuals while being unconscious. The instruments we have today assess individuals' conscious state. Try ask them what they can do if earthquake occurs and they will know. But, when earthquake really strikes, they panic and remember nothing instead" [21].

\section{Discussion}

Based the results identified several points of opportunity for school counselors to take part in disaster preparedness education, collaborating with non-governmental organizations.

1. Preparation for providence of disaster preparedness education 
First, school counselors participate in trainings conducted by NGOs. The knowledge they obtain should then be transferred to other teachers in schools because all teachers share the same responsibilities for disaster preparedness. Trainings aim at increasing school resilience because school resilience levels also depend on the providence of disaster training program for schoolteacher or staffs and teachers' active participation in disaster-related program [25]. Interactive method is considered more suitable and therefore should be adopted for teacher disaster preparedness trainings. Some of the interactive models are: 1) group discussions that involve skills such as logical thinking, arguing, listening, and respecting differences; 2) demonstration based on previous observations, 3 ) conference that puts a high priority on participant's active participation in trainings and trainers' roles in guiding, managing, controlling, and initiating discussion; 4) visits to related institutions or organization; 5) role play to allow participants to take active participation both mentally, and physically; and 6) learning while copying so that teachers can not only receive information but also practice various instructions correctly for simulation purpose [26]. Those steps are expected to build collaboration and responsibilities among parties involved in disaster preparedness efforts in school such as school counselors, subject teachers, and school principals to minimize the impacts of disaster.

Second, school counselors play a huge role in assisting coordination between NGOs and school principals to minimize misunderstanding of disaster preparedness education providence in schools. In addition, coordination also aims to provide understanding and raise awareness of the fact that responsibilities for the program are in the hands of all parties and not just one or two. Disaster preparedness is one of long-term programs and therefore requires longterm collaboration. It is expected that, in the end, this collaboration can provide bureaucratic members with outlook on fun disaster preparedness education concepts for students.

\section{Types of intervention provided in disaster preparedness}

Due to the focus of the program on changing behavior in form of appropriate responses to disaster, school counselors and NGOs can intervene by conducting disaster simulation drills in schools. Simulations are designed according to the potential types of disaster in the area. They aim at training students mentally to assure students' disaster preparedness. Simulations are beneficial for improving students' knowledge in the face of certain disaster. This is in line with results of a previous study on earthquake. It was found that earthquake preparedness simulations can improve students' knowledge in the face of earthquake [27]. This knowledge is about earthquake phenomena, possible dangers that people may face mitigation efforts, and emergency actions to be taken. Other references argued that simulations can help individuals improve their communication skill, teamwork, knowledge of self-care strategy, understanding of possible threats, and preparation or best response to disaster [28]. Therefore, it can be said that simulations make positive impacts on not only knowledge but also actions of the students before, during, and after disaster.

Subsequently, school counselors and NGOs collaborate to create or share materials on mitigation of spiritual aspect. Materials can be presented using conventional lecture method or film during classical guidance session to provide students with understanding that every disaster happens within God's providence and raise awareness that disasters may be caused by human bad deeds such as sinful acts, littering, and bribing people to fire the forests. Spiritual aspect should focus on not only mitigation efforts but also post-disaster recovery process as it is linked to psychological conditions of survivors. Previous studies found that religion and spirituality play a huge role in helping survivors during recovery process. Religion and spirituality also function as supports in the event of disaster negative impacts and individual psychological pressure after disaster [29]. This belief in God also completes treatment management process using mitigation approach that focuses on understanding of the nature of disaster and management effectiveness without ignoring local cultures [30]. Previous studies believed that spiritual level correlates negatively with depression and anxiety caused by disaster trauma exposure. The more positive religious belief and spirituality of an individual, the more resilient he is to material and immaterial effects of disaster [29].

\section{Products/innovations to be developed}

The first innovation that needs to be developed is simple games that adopt disaster preparedness theme. The games will be one of techniques to be selected in providing services for both preventive and curative purposes. However, since not all regions in the country have access to proper electronic devices, the games should be designed to be played without electronic devices. The use of game-based method in education for disaster preparedness is proved more effective in increasing students' knowledge about disaster risks compared to conventional lecture method. Game-based method is even considered an innovation in disaster preparedness education that can be used to promote behavior in disaster risk management among students [31]. Gamebased method also provides students with collaboration experiences in solving a problem to raise awareness of disaster risks, improve ability to identify dangers, increase prevention skills, empathy, and perspective-taking [32]. It can be said that students more readily accept game-based method since the method allows them to experience new things related to disaster preparedness.

Second, together with NGOs, providing children with child friendly spaces to help maintain students' psychosocial conditions in school. The design of child friendly spaces will allow students to interact with the people around them and show them care. The space design should adopt children participation principles to make the space a place that supports education activities and a place to play freely, to increase socializing skills, and to study. However, this function should be adjusted to students' age levels in each school [33]. Schools with students from early ages should give priority to play-based learning activities to suit students' developmental stage. Meanwhile, schools with teenage students can focus on conducting directed group discussions. Besides for prevention, child friendly spaces are provided for post-disaster management to erase potential trauma among children. Post-disaster psychological recovery activities conducted in child friendly spaces are almost similar to prevention activities, which include drawing, learning, singing, playing, and other fun activities for children [34]. 
Positive activities in child friendly spaces are expected to minimize psychological impacts of disaster among children.

Third, disasters basically give students overwhelming influences as they belong to vulnerable group of people. Students, particularly those at young age, have not grown mature psychologically and are therefore prone to long-term psychological problems after disaster strikes. Conditions are worsened without a good care and preventive action. Preventive efforts can be made by doing early detection through identification process using assessment instrument.

The instrument highlighted in this study is the one to assess students' responses in panic or unconscious situations. By using this instrument, it is expected that individual spontaneous responses when disaster strikes can be identified earlier. Therefore, post-disaster psychological impacts that cause changing behavior such as increased sensitivity, overanxiety, and withdrawal behavior can be minimized [35].

\section{CONCLUSION}

There are opportunities for school counselors and nongovernmental organizations to collaborate in providing disaster preparedness education in schools including participation in disaster preparedness trainings, provision of assistance in organization-school principal coordination in conducting disaster preparedness education in school, execution of disaster simulation drills to change behavior and train students to be mentally prepared for disaster, implementation of mitigation in spiritual aspect, design of simple games about disaster preparedness, design of child friendly spaces to maintain children's psychosocial conditions, and creation of instrument to assess individual responses while panicking. Those all seven collaboration opportunities can be used as reference for schools, particularly school counselor, together with NGOs, to provide disaster preparedness education based on students' developmental stages and potential types of disaster in the area. Moreover, counselors' knowledge and understanding of providing disaster preparedness education together with NGOs can be used as materials for discussions or promotion of the program among educators. Therefore, there will be more teachers being educated and touched to participate in providence of disaster preparedness education in school. It is also expected that results of this study can be used as a reference for future studies about collaboration between school counselors and other parties related to disaster preparedness efforts.

\section{ACKNOWLEDGMENT}

Researcher would like to thank the Ministry of Research, Technology, and Higher Education of Republic of Indonesia (Kemenristekdikti RI) for funding this research.

\section{REFERENCES}

1] D.N. Sattler, M. Claramita, and B. Muskavage, "Natural disasters in Indonesia: relationships among posttraumatic stress, resource loss, depression, social support, and posttraumatic growth," Journal of Loss and Trauma, vol. 23, pp. 1-15, January 2018.

[2] Bappenas. "Pengurusutamaan penanggulangan bencana dalam perencanaan pembangunan," Bappenas: 2016 (Accesed: 4th October 2019)

[3] Badan Nasional Penanggulangan Bencana. (2019). Data informasi bencana Indonesia tahun 2018-2019. Retrieved September 30, 2019, from http://bnpb.cloud/dibi/tabel1b
[4] D. Kurniawati, and Suwito."Pengaruh pengetahuan kebencanaan terhadap sikap kesiapsiagaan dalam menghadapi bencana pada mahasiswa program studi pendidikan geografi Universitas Kanjuruhan Malang," Jurnal Pendidikan dan Ilmu Geografi, vol. 2, pp. 135-142, September 2017.

[5] M. Dokhi, T. H. Siagian, A. P. Utomo, and E. Rumanitha, "Social capital and disaster preparedness in Indonesia: a quantitative assessment through binary logistic regression," Springer International Publishing, vol. pp. 589-608, August 2017.

[6] B. Rahmat. "Kak Seto: penanganan anak-anak korban bencana jadi prioritas," (Accesed : 4th October 2019). Retrieved from: https://www.cnnindonesia.com/nasional/20160703021957-20142673/kak-seto-penanganan-anak-anak-korban-bencana-jadiprioritas.

[7] J. Tatebe, and C. Mutch, "Perspectives on education, children and young people in disaster risk reduction," International Journal of Disaster Risk Reduction, vol. 14, pp.108-114, December 2015.

[8] N. Aghaei, H. Seyedin, and H. Sanaeinasab, "Strategies for disaster risk reduction education: a systematic review," Journal of Education and Health Promotion, vol. 7, pp. 1-8, August 2018

[9] E. Frankenberg, B. Sikoki, C. Sumantri, W. Suriastini, and D. Thomas, "Education, vulnerability, and resilience after a natural disaster," Ecology and Society, vol. 18, pp._, , 2013.

[10] V. A. Johnson, K. R. Ronan, D. M. Johnston, R. Peace, "Implementing disaster preparedness education in New Zealand primary schools ," Disaster Prevention and Management, vol. 23, pp. 370-390, July 2014.

[11] S. Torani, P. M. Majd, S. S. Maroufi, M. Dowlati, and R. A. Sheikhi, "The importance of education on disasters and emergencies: a review article" Journal of Education and Health Promotion, vol 8, pp. April 2019

[12] N. Khoirunisa, "Disaster knowledge of student for disaster preparedness," Friendly Education, pp. 219-222, May 2016.

[13] H. Aprilin, S. Haksama, and Makhfludi, "Kesiapsiagaan sekolah terhadap potensi bencana banjir di SDN Gebangmalang Kecamatan Mojoanyar Kabupaten Mojokerto,” Jurnal Biosains Pascasarjana, vol. 20, pp. 1-13, 2018

[14] P. Marskole, A. Mishra, P. Kumar, P. Gaur, P. Aharwar, P. Patidar, and P. Shejwar, "A study to assess awareness on disaster management among school going children in Gwalior (M.P.)," International Journal of Community Medicine and Public Health, vol. 5, pp. 1371-1375, April 2018.

[15] J.J. Wang, "Study on the context of school-based disaster management," International Journal of Disaster Risk Reduction, vol. 19 , pp. 224-234, September 2016

[16] A. Rahma, "Implementasi program pengurangan risiko bencana (prb) melalui pendidikan formal," Varia Pendidikan, vol.30, pp. 1-11, July 2018.

[17] A. K. Dube, and J. A. Orodho, "Level of disaster preparedness and policy implementation in public secondary schools in Rhamu Town, Madera County, Kenya," Journal of Research \& Method in Education, vol.6, pp.6-11, March-April 2016.

[18] R. L. Brocque, A. D. Young, G. Montague, S. Pocock, S. March, N. Triggeli, C. Rabaa, and J. Kenardy, "Schools and natural disaster recovery: the unique and vital role that teachers and education professionals play in ensuring the mental health of students following natural disasters", Journal of Psychologists and Counsellors in Schools, vol. 27, pp. 1-23, Juni 2017.

[19] Z. Septikasari, M. Fauziah, and I. B. Handaka, "Peran layanan bimbingan dan konseling dalam penanggulangan bencana," Proceeding of The 8th University Research Colloquium 2018 Universitas Muhammadiyah Purwokerto, vol. __, pp. __, November 2018.

[20] Amri, A. Challenges in implementing disaster risk reduction education: Views from the frontline in Indonesia. Sydney, Australia: Macquarie University, 2015.

[21] Focus Group Discussion with UNY's disaster preparedness research team on May 19, 2019 at Century Park Hotel, Jakarta.

[22] A. W. W. Syadzwina, M. Akbar, and T. Bahfiarti, "Fenomenologi perilaku komunikasi suporter fanatik sepakbola dalam memberikan dukungan pada psm makassar," Jurnal Komunikasi Kareba, vol. 3, pp. 1-7, January 2014.

[23] Sugiyono. Metode peelitian kuantitatif, kualitatif, dan r\&d. Bandung, Indonesia: Alfabeta, 2014.

[24] M. D. Ghony and F. A. Manshur. Metodologi penelitian kualitatif. Yogyakarta, Indonesia: Ar-Ruzz Media, 2012. 
[25] T. Thi and R. Shaw, "School-based disaster risk reduction education in primary schools in Da Nang City, Central Vietnam", Environmental Hazards, vol. 15, pp. 356-373, August 2016.

[26] Y. O. Izadkhah, M. Hosseini, and V. Heshmati, "Training teachers on disaster risk reduction in developing countries: challenges and opportunities," Proceeding of 15th World Conference on Earthquake Engineering 2012, vol. 1, pp. 17809-17816, September 2012.

[27] S. A. Sari, M. Dirhamsyah, and P. Z. Finzia., "The influence of earthquake disaster risk reducation simulation towards the preparedness knowledge for elementary school student of Ulee Paya, Pulo Breuh, Aceh Besar, Indonesia," International Journal of Education and Research, vol.2, pp. 419-426, September 2014.

[28] K. W. Zavaleta, U. Asirvatham, B. Callies, W. B. Franz, L. S. Hanson, and R.B. Molella, "Improving community resilience through disaster simulation: how simulation-based education augments emergency management exercises," Journal of Homeland Security and Emergency Management, vol. 15, pp. 1-7, July 2018.

[29] J. D. Aten, K. A. O'Grady G. Milstein, D. Boan, and A Schruba, "Spiritually oriented disaster psychology," Spirituality in Clinical Practice, vol. 1, pp. 20-28, March 2014.

[30] K. M. Ha, "The role of religious beliefs and institutions in disaster management: a case study," Journal Religions, vol. 6, pp. 13141329, November 2015.

[31] M. J. Moradian and Z. M. Nazdik, "Game versus lecture-based learning in disaster risk education; an experience on Shiraz High School Students," Bull Emerg Trauma, vol. 7, pp. 112-117, April 2019.
[32] A. Solinska, P. Magnuszewski, M. Curl, A. Frenc, A. Keating, J. Mochizuki, W. Liu, R. Mechler, M Kulakowska, and L. Jarzabek, “An overview of serious games for disaster risk management - prospects and limitations for informing actions to arrest increasing risk," International Journal of Disaster Risk Reduction, vol. 31, pp. 10131029, September 2018

[33] Yayasan Sayangi Tunas Cilik. Aksi untuk prestasi: menuju sekolah dan masyarakat siaga bencana di Jakarta Utara. Jakarta, Indonesia: Yayasan Sayangi Tunas Cilik.

[34] Save the Children. (2018). Ruang ramah anak bantu atasi potensi trauma pada anak-anak paska gempa Lombok. Retrieved October 1, 2019, from https://www.stc.or.id/news/ruang-ramah-anak-bantu-atasipotensi-trauma-pada-a.

[35] Z. Thoyibah, M. Dwidiyanti, M. Mulianingsih, W. Nurmayani, and R. I. Wiguna, "Gambaran dampak kecemasan dan gejala psikologis pada anak korban bencana gempa bumi di Lombok," Journal of Holistic Nursing and Health Science, vol. 2, pp. 31-38, June 2019. 